\title{
A Pioneer in the Study of Affective Forecasting
}

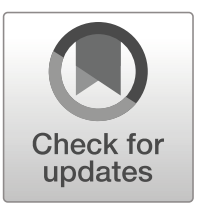

\section{Adrian Tomyn ${ }^{1}$}

Received: 31 May 2019 / Accepted: 1 August 2019/Published online: 9 September 2019

(C) The International Society for Quality-of-Life Studies (ISQOLS) and Springer Nature B.V. 2019

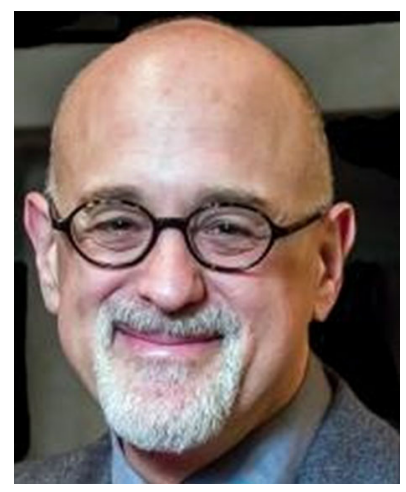

Daniel Gilbert is the Edgar Pierce Professor of Psychology at Harvard University. He has won numerous awards for his teaching and research, including the Diener Award for Outstanding Contributions to Social Psychology from the Foundation for Personality and Social Psychology (2008), the Donald T. Campbell Award from the Society for Personality and Social Psychology (2017), and the William James Award from the Association for Psychological Science for "a lifetime of significant intellectual contributions to the basic science of psychology." In 2008, he was elected to the American Academy of Arts and Sciences.

Gilbert was born in 1957 to the molecular geneticist Lawrence I. Gilbert and the actress, artist, and author Doris Gilbert. He grew up in Chicago, but dropped out of high school at the age of 16 to travel around the United States, ultimately landing in Denver, Colorado where he became a science fiction writer. After publishing several stories in outlets such as Amazing Stories and Isaac Asimov's Science Fiction Magazine, he decided to take a writing class at a local community college. When he went to register, he found the course was full, so he signed up for the only course that was still open: Introduction to Psychology. His interest in the topic was piqued, and he soon enrolled at the University of Colorado at

Adrian Tomyn

adrian.tomyn@gmail.com

1 School of Psychology, Deakin University, Melbourne, Australia 
Denver, where he received a B. A. in 1981. Gilbert studied with Edward E. Jones at Princeton University and received his Ph.D. in 1985. He joined the faculty of the University of Texas at Austin in 1985, and the faculty of Harvard University in 1996.

In the late 1980's, Gilbert proposed that the mind generates quick, simple, unconscious inferences that are then corrected by conscious scrutiny, and that this second process often fails because it requires more resources than the first. His initial paper on this topic (Gilbert et al. 1988) was named a "Modern Classic in Social Psychology" (Stasser and Titus 2003) by Psychological Inquiry, and remains one of the 20 most cited articles in JPSP from 1965 to 2000 (Quinones-Vidal et al. 2004). In the early 1990's, Gilbert applied this general idea to the problem of belief, developing a model that explains a wide variety of phenomena, from truth bias to gullibility, and whose roots he traced to Spinoza (Gilbert 1991). The Spinozan model continues to be debated by psychologists and philosophers, and it was the basis for his Distinguished Scientific Contribution Award for an Early Career Contribution to Psychology given by the American Psychological Association in 1992.

But Gilbert's contribution to the study of well-being and quality of life studies lies in a third body of work that he began in the late 1990's with his longtime collaborator, Timothy Wilson, on how and how well people can predict their hedonic reactions to future events. The pair's research on affective forecasting (Gilbert et al. 1998) has spawned hundreds of studies and thousands of citations, and has impacted fields as far flung as law, finance, and medicine. Gilbert and Wilson's general concern with how human beings think about the future - a process they dubbed "prospection"- has itself become a highly active area of investigation by psychologists and neuroscientists.

In addition to his scientific contributions, Gilbert has become one of psychology's most recognizable public figures. His essays have appeared in a variety of major media outlets including NPR and the New York Times, and his 2007 trade book, Stumbling on Happiness, won the Royal Society's General Book Prize for best science book of the year, spent six months on the New York Times bestseller list, and sold about a million copies world-wide, making it one of the best-selling popular psychology books of all time.

Gilbert's three TED talks have attracted more than 20 million viewers, and the first remains one of the most-watched TED talks ever. In 2010, he co-wrote and hosted a 6-h television series for PBS on the psychology of emotion. This Emotional Life won several Telly awards and was seen by almost 10 million viewers the week it debuted. In 2013, Gilbert teamed up with Prudential to create a series of highly successful television ads to illustrate the psychological obstacles to retirement savings.

\section{References}

Gilbert, D. T. (1991). How mental systems believe. American Psychologist, 46.

Gilbert, D. T., Pelham, B. W., \& Krull, D. S. (1988). On cognitive busyness: When person perceivers meet persons perceived. Journal of Personality and Social Psychology, 54.

Gilbert, D. T., Wilson, T. D., Pinel, E. C., Blumberg, S. J., \& Wheatley, T. P. (1998). Immune neglect: A source of durability bias in affective forecasting. Journal of Personality and Social Psychology, 75(3).

Quinones-Vidal, Lopez-Garcia, Peneranda-Ortega, \& Tortosa-Gil. (2004). The nature of social and personality psychology as reflected in JPSP, 1965-2000. Journal of Personality and Social Psychology, 86, 435-452.

Stasser, G., \& Titus, W. (2003). Hidden profiles: A brief history. Psychological Inquiry (2003), 14(3-4), 304-313.

Publisher's Note Springer Nature remains neutral with regard to jurisdictional claims in published maps and institutional affiliations. 